\title{
Assessment Model on Cooling Effect of Mangrove and Proboscis Monkey Conservation Area in Tarakan City
}

\author{
NUZULA ELFA RAHMA $^{1}$ AND YULMA $^{2}$ \\ ${ }^{1}$ Study Programme of Environmental Management, Department of Agricultural Management, \\ Agricultural Engineering Polytechnic Institute of Samarinda, Samarinda, Indonesia \\ ${ }^{2}$ Department of Water Resources Management, Faculty of Fisheries and Marine Sciences, University \\ of Borneo Tarakan, Tarakan, Indonesia
}

\begin{abstract}
A conservation area for mangrove forests and proboscis monkeys locates within a dense urban centre in Tarakan city. Its surrounding area has rapidly transformed into condensing urban artificial structures with minimal vegetation cover. The study aims to determine the cooling effect of the conservation area toward its surrounding. The study applies model assessment, which comprises ENVI-MET for simulation of air temperature distribution, and Rayman for PMV (Predicted Mean Vote) calculation to investigate the level of heat stress. The result shows that the mangrove cover has a cooling effect effectively after midnight to 11.00 $\mathrm{AM}$ the subsequent day. Specifically, for the surrounding area, it is confined within an 8-hour window (from 0.00 to $8.00 \mathrm{AM}$ ). Within this window, inside the mangrove area, ENVI-MET generates significantly lower air temperature, when compared to its surrounding. The mangrove presence correlates to reducing air temperature up to $1.8{ }^{\circ} \mathrm{C}$. The cooling effect also extends to its surrounding with a limited radius (approximately $10 \mathrm{~m}$ ). However, PMV calculation implies that there is no significant improvement in thermal comfort as a result of the mangrove presence. The results may not adequately reflect the reality in the field. Further research to calibrate PMV measurement that involves human monitoring is required to validate the findings.
\end{abstract}

Keywords: urban heat island, mangrove forest, Tarakan

\section{INTRODUCTION}

With the central government's commitment to better equality in economic growth and infrastructure for the farthest region of Indonesia, Tarakan city is determined to be the leading city in this effort. It is not without some challenges. As the island city, Tarakan is vulnerable both in the face of natural disasters and climate change.

Moreover, Tarakan is also facing pressure from anthropogenic activities. In 2013, statistic records stated that Tarakan inhabitants were 218,792 people. Within five years, the number has soared to 262,025 people (BPS Kota Tarakan, 2019), meaning that Tarakan has

Correspondence: Nuzula Elfa Rahma, Agricultural Engineering Polytechnic Institute. Jl. Sam Ratulangi, Samarinda, Indonesia. Email: elfarahma@gmail.com grown $19.76 \%$ (or $3.67 \%$ per year) of the population. The statistic is staggering and provides an insight into what kind of constraint that burden Tarakan. The island covers a land area as wide as $250.80 \mathrm{~km}$ square, which means that population density is around 1,044 lives per $\mathrm{km}$ square. Given the current high population growth rate, Tarakan is facing a further loss of land area in favor of the settlement, business center, or another artificial structure allotment.

The forest cover of Tarakan island is approximately 25,282 ha that divides between protection forest (6,997 ha) and other uses $(18,285$ ha), based on Environment and Forestry Ministerial Decree on the Designation of Provincial Forest in 2014 (BPS Provinsi Kalimantan Utara, 2019). Typically, as a coastal island city, mangrove forest could be seen naturally grows along the coastal area. There is also a conservation area that covers 21 ha of 
mangrove forest, which serves as the city landmark mainly because of its Proboscis monkey inhabitants.

Massive vegetation cover loss may lead to disturbance of the climate system. Its effect goes within a global and local scale. On the global scale, vegetation cover loss adds up carbon emission to the atmosphere, which is causing the rise of global temperature. On a local scale, if combined with the effect of expanding human-made structures, vegetation cover loss may contribute to the urban heat island (UHI) phenomenon.

The UHI phenomenon refers to a circumstance when an urban area is warmer when compared to the surrounding nonurban/rural area (Adinna et al., 2009). The warming effect occurs due to the ability of artificial structures to capture solar radiation rather than reflecting it to the atmosphere. The absorbed radiation eventually brings more heat, creating an isolation dome that enclaves the urban space (Nuruzzaman, 2015). The human body reacts to UHI with a sense of discomfort. For Tarakan, being in the tropical region means that the level of discomfort tends to be high. When people collectively become uncomfortable with warmer weather, the implication is dire. People may adapt by using air conditioner more, being more reluctant to walk, and prefer to commute with private car or motorcycle. Needless to say that the behavior leads to more fossil fuel consumption and more $\mathrm{CO}_{2}$ emit to the atmosphere. Contributing to even more heat and eventually more discomfort (Karyono, 1995).

The perpetual cycle needs to be acknowledged by the Tarakan urban planner. Otherwise, the decline in quality of life, as well as the environment, would be inevitable. Therefore, the study proposes to examine the cooling effect of a mangrove land cover in Tarakan city, as well as how it may affect the level of thermal discomfort for its inhabitants.

\section{METHODOLOGY}

\section{Study Area}
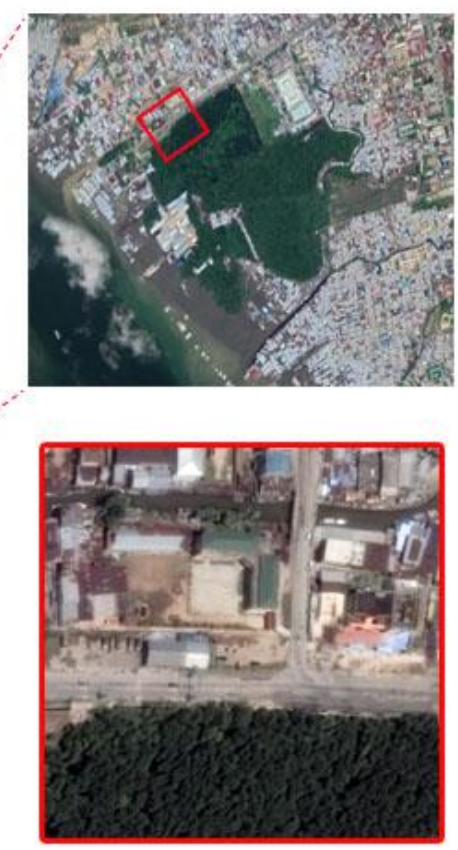

Figure 1. Aerial view of Tarakan Island with the location of the study area

For the study area, we select Kawasan Konservasi Mangrove dan Bekantan (KKMB) or Conservation Area for Mangrove and Proboscis Monkey in Tarakan Island. The island is part of North Kalimantan, an Indonesian province that shares a border with Sabah, a Malaysian state in Borneo. Latitude longitude coordinates for Tarakan 
are $3^{\circ} 18^{\prime} 47.95^{\prime \prime} \mathrm{N}$,

$117^{\circ} 35^{\prime} 29.47^{\prime \prime E}$.

The location of KKMB is within Tarakan urban center with an area as large as 21 ha (Figure 1). KKMB was established in 2001 and initially reserved for 9 ha before Tarakan Municipality legally expanded the area to become 21 ha in 2006. Natural forest characterizes the origin area. While the expansion area is a rejuvenated forest that has a history of being cleared and has been replanted throughout the years. Five distinct tree species inhabit KKMB, in which Rhizophora apiculata as the dominant one with 42.28\% of Relative Dominance (Sawitri et al., 2013). KKMB mangrove is considered as healthy mangrove with a density as much as 11,700 individual/ha (Salim et al., 2019).

The inland area of KKMB is at the northwest side, which gradually shifts to the wetter area as it spreads to the eastern side. At the northwest side, the mangrove meets the main road that enables visitors to access the area. The road itself is two-lane asphalt street, which is approximately $20 \mathrm{~m}$ wide. As seen on a satellite image (Figure 1), the mangrove area is surrounded by dense artificial structures, mostly belong to settlement, commercial, roads, and concrete pavement.

Very few vegetation covers the surrounding area, confirmed by ground inspection in which

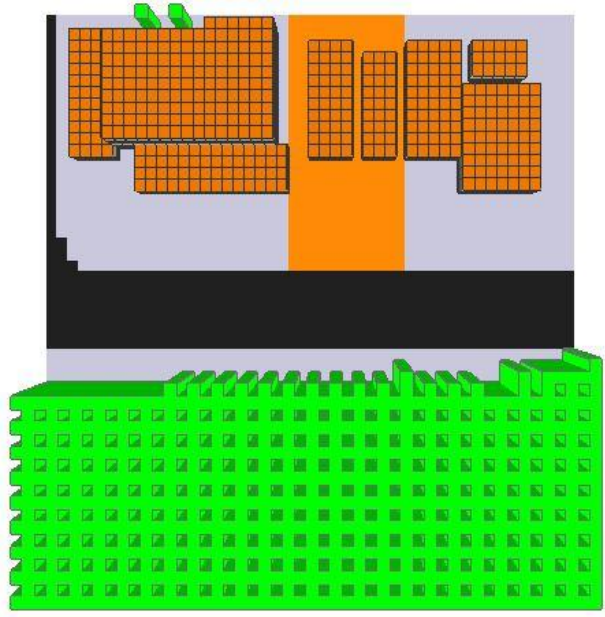

the appearance of trees that able to provide shade is nearly absent. Bush and grass dominate the green cover, often found in some patches of soil or through the damaged concrete pavement.

\section{Model Simulation}

To perform the analysis, we run ENVI-MET (Ambrosini et al., 2014) and Rayman (Matzarakis et al., 2007), two software that aims to simulate urban microclimate. It specifically addresses how urban settings may divert flow fluidity and heat exchange, which in turn affecting urban climate (Manteghi et al., 2016).

\section{ENVI-MET Simulation}

For the model input, we acquire a satellite image of KKMB from Google Earth, which later digitized to replicate the geometry of the urban structure. By incorporating those elements, we obtain a map with topography visualization, as seen in Figure 2. The dimension for the digitized map is $50 \times 50 \times 10$ of two meters resolution in ENVI-MET grid-scale or equivalent to $100 \mathrm{x}$ $100 \times 20 \mathrm{~m}$, which is under mesoscale or urban boundary layer in term of urban meteorology.

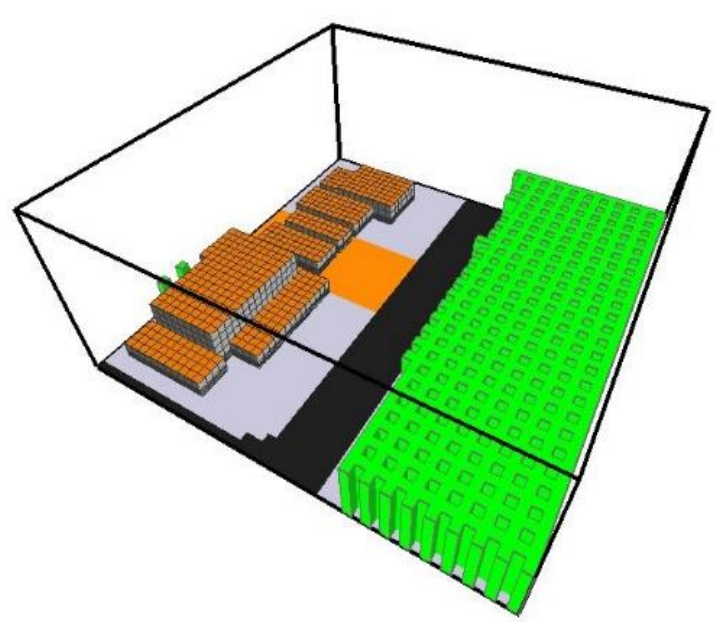

Figure 2. 3D Visualization of the study area

Digitization is the act of attributing each grid with its corresponding characters based on the system profile database. The database compiles characteristics like building material, soil profiles, surfaces, and plant physiology. By default, ENVI-MET does not have a system 
profile that mimics the mangrove ecosystem. Therefore, we customize the user database to set a plant system and surfaces to model the mangrove ecosystem. Customization of plant profile is as follows: $10 \mathrm{~m}$ for height, very dense, and with leafless base. To represent the surface underneath the mangrove, which happens to be a water body, "water" is deployed as an attribute. Another setting comprises; asphalt for the main road, used/dirty concrete for pavement, loamy soil for inland soil profile, and concrete for building material without greening facade for the roof. ENVI-MET simulation time range is set for 24 hours, from 08.00 AM on $23^{\text {rd }}$ June to 07.00 AM on the next day. After finishing, the simulation would provide data output for each hour. The basic setting for meteorological parameters is in Table 1.

Table 1. ENVI-MET basic settings for meteorological parameters.

\begin{tabular}{ll}
\hline Basic Setting & \\
\hline Temperature & $23{ }^{\circ} \mathrm{C}$ at $06.00 \mathrm{AM}$ (minimum) \\
& $34{ }^{\circ} \mathrm{C}$ at $02.00 \mathrm{PM}$ (maximum) \\
Relative Humidity & $70 \%$ at $02.00 \mathrm{PM}$ (minimum) \\
& $80 \%$ at $06.00 \mathrm{AM}$ (maximum) \\
Wind speed & $2.0 \mathrm{~m} \mathrm{~s}^{-1}$ \\
Wind direction & East-west $\left(90^{\circ}\right)$ \\
\hline
\end{tabular}

\section{Scenario}

At the end of the simulation, ENVI-MET generates a map that visualizes the difference in the chosen climate parameter, which we use to select sample grids for further scenario analysis.
We establish three scenarios that represent different land cover, which is: 1) inside mangrove area, 2) the main road at the northwest side of the mangrove, and 3) the pavement in the urban neighborhood across the mangrove area (as shown in Figure 3).

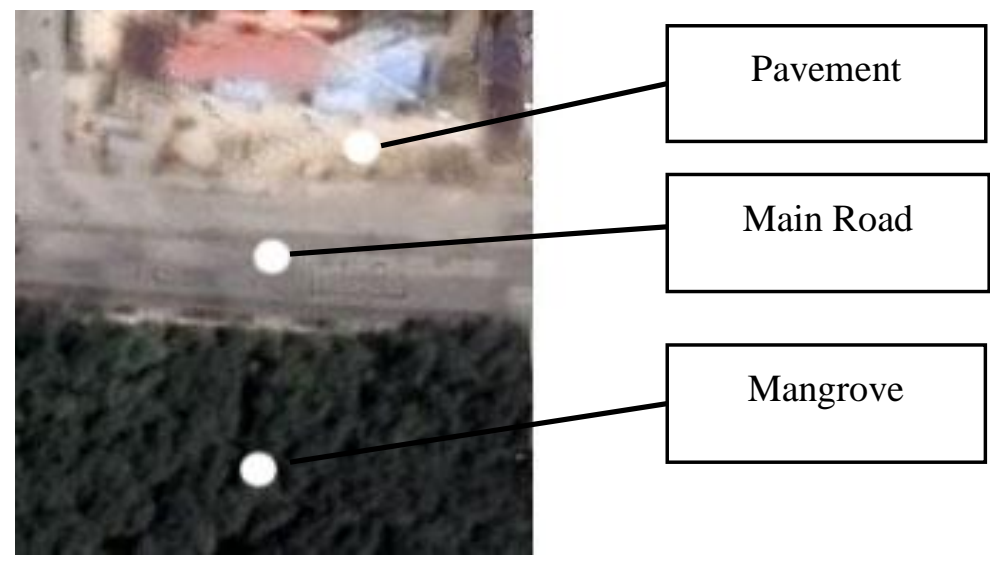

Figure 3. Three selected grids at the study area

\section{PMV Calculation}

The result from ENVI-MET later is analyzed in Rayman software to calculate PMV (Predicted Mean Voted) as a parameter to define thermal comfort. Additional data of the human biology parameter is required (See Table $2)$. The clothing index defines the extensiveness Journal of Wetlands Environmental Management Vol 9, No 1 (2021) 29 - 37 http://dx.doi.org/10.20527/jwem.v9i1.251 of a person's clothing in which numeral one (1) refers to winter clothing. PMV index comes in range, from -3 to +3 . The spectrum corresponds to thermal acceptability that later translated into a qualitative index (Table 3). Recommended PMV index range is between -0.5 and +0.5 (ASHRAE, 2017). 
Table 2. Basic settings for the human factor in Rayman

\section{Basic setting}

$\begin{array}{ll}\text { Height } & 1.75 \mathrm{~m} \\ \text { Weight } & 75 \mathrm{~kg} \\ \text { Age } & 35 \\ \text { Sex } & \text { Male } \\ \text { Clothing } & 0.75 \\ \text { Activity } & 80\end{array}$

Table 3. Qualitative thermal acceptability of PMV scale (Taweekun, 2013)

Value

$+3$

$+2$

$+1$

0

$-1$

$-2$

$-3$

\section{Thermal acceptability}

hot

warm

slightly warm

neutral

slightly cool

cool

cold

\section{RESULTS AND DISCUSSION}

Figure 4 shows the output of ENVI-MET simulation during the diurnal and nocturnal period, that presents trajectories from each of the three scenarios. They exhibit different behavior that corresponds to a different period of the day.

The nighttime (nocturnal) period data shows that the air temperature pattern of the mangrove area aligns with the main road and pavement, up to 00.00 AM. Afterwards, mangrove's air temperature goes a separate direction. Mangrove's air temperature continues to descend, whereas both the pavement and the central road temperature start to ascend. At 4.00 AM, approximately two hours before sunrise, the air temperature in the mangrove is at the lowest before it begins to increase. Also note that at this hour, the difference between the mangrove area and two other points is at the greatest. The difference in air temperature at the mangrove area and the pavement is $1.8{ }^{\circ} \mathrm{C}$ and $1.5{ }^{\circ} \mathrm{C}$ for the main road respectively. For comparison, at $00.00 \mathrm{AM}$, the difference between mangrove and pavement is only 0.03 ${ }^{\circ} \mathrm{C}$.

How about the effect of the mangrove to its surrounding? As Figure 4 shows, the main road and pavement's graphs consistently align during the day and up until 0.00 AM. However, the graphs diverge at $0.00 \mathrm{AM}$, in which the main road's air temperature goes slightly lower than the pavements. The difference is approximately $0.3^{\circ} \mathrm{C}$ that takes place from $0.00 \mathrm{AM}$ to 7.00 AM. The pattern implies that there is a correlation between the main road's proximity to the mangrove and its cooler temperature, despite the event only takes place in the 8-hour window after midnight.

The asphalt, as the surface attribute for the main road, probably also play a role here. Different surface attribute differs in terms of albedo, the ability of a particular surface to reflect radiation (Dobos, 2005). The higher a particular surface's albedo, the lower its ability to contain heat from radiation. However, the ENVI-MET database shows that the default 
albedo from the pavement is $30 \%$. The albedo implies that the pavement reflects $30 \%$ of the radiation exposure to it. It is higher than asphalt, which only measured at $20 \%$. That the pavement's albedo is higher, is confirmed by
Skoufali and Battisti (2019). The study implies that the main road's surface is not a factor that contributes to its cooler temperature. Thus, the effect of the main road's surface could be omitted.

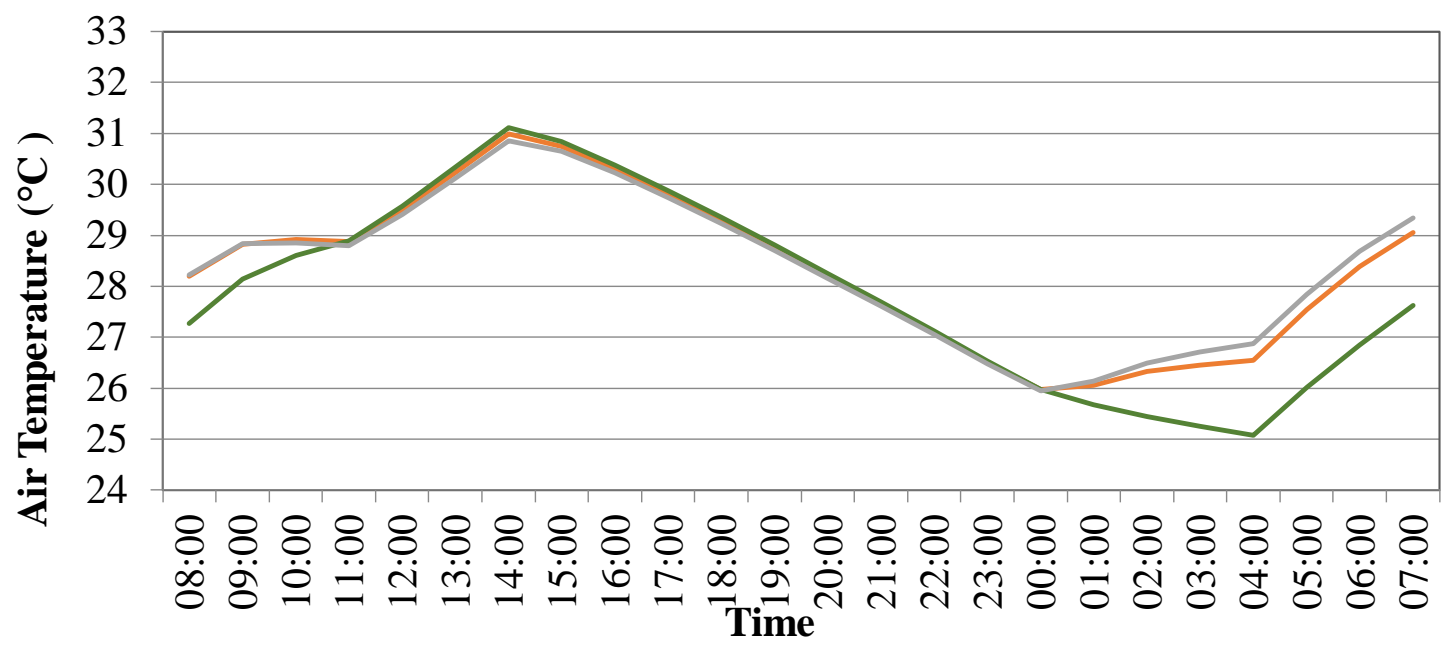

—Main Road —Mangrove — Pavement

Figure 4. Air temperatures in 24-hour ENVI-MET simulation

To sum up, the ENVI-MET result suggests that the UHI phenomenon does occur, although it is only prevalent in the second half of the nocturnal period. In this case, The U.S. Environmental Protection Agency (2008) confirms that UHI occurrence in an atmospheric scale is indeed to be more prevalent at night due to the slow capacity of urban structure to release heat.

Furthermore, despite only in a limited radius, the greenery of mangrove may have an impact on nearby artificial surfaces. Air temperature distribution (Figure 5) indicates that the most substantial cooling effect is within a radius of approximately $10 \mathrm{~m}$. At a distance exceeding 10 $\mathrm{m}$, the effect gradually declines, and after a radius of approximately $15 \mathrm{~m}$, it becomes obsolete.

When converting simulation output into thermal acceptability by using Rayman, the result turns out to be counter-intuitive. For instance, PMV of the mangrove area during mid-day (02.00 PM) is higher than PMV of the pavement and the main road. The PMV in the mangrove area indicates "extreme heat stress," while PMV in the pavement and the main road fall into "strong heat stress." Meaning that during the day, the air temperature in the main road and pavement are more comfortable than in the mangrove area. Although it could be explained because of the wind speed within the urban area, simulated by ENVI-MET, is significantly higher. The wind speed for the pavement grid point is $2.4 \mathrm{~m} / \mathrm{s}$ at $02.00 \mathrm{PM}$ and $2.5 \mathrm{~m} / \mathrm{s}$ for the main road at the same time. In contrast, wind speed for the mangrove area is $1.6 \mathrm{~m} / \mathrm{s}$. The wind speed simulation aligns with a finding from Bornstein and Johnston (1977) that states urban wind speed tends to surpass the rural counterparts. Droste et al. (2018) also agree with this finding. 


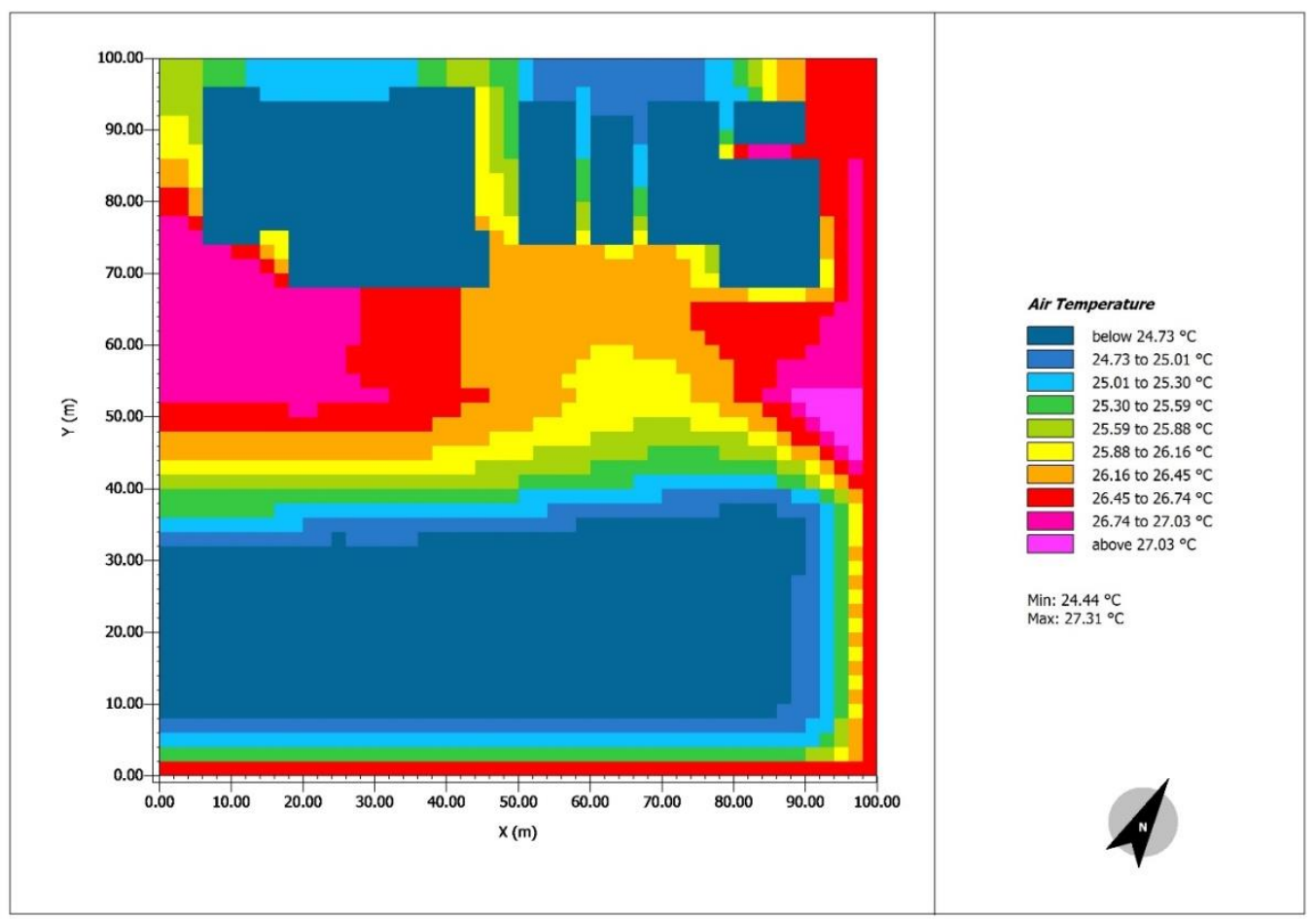

Figure 5. Air temperature distribution at $04.00 \mathrm{AM}$

In general, the Rayman result implies that the mangrove area does not have an impact on reducing heat stress to the acceptable level. This is particularly true for its surrounding. The acceptable PMV measure for humans is between -0.5 and +0.5 . In contrast, Rayman simulation shows that by late morning $(09.00$
AM) to late afternoon (03.00 PM), and at all selected points, PMV measurement is always at three or above. Also, unlike air temperature simulation, the mangrove presence does not seem to have an after-midnight impact (as shown in Figure 6).

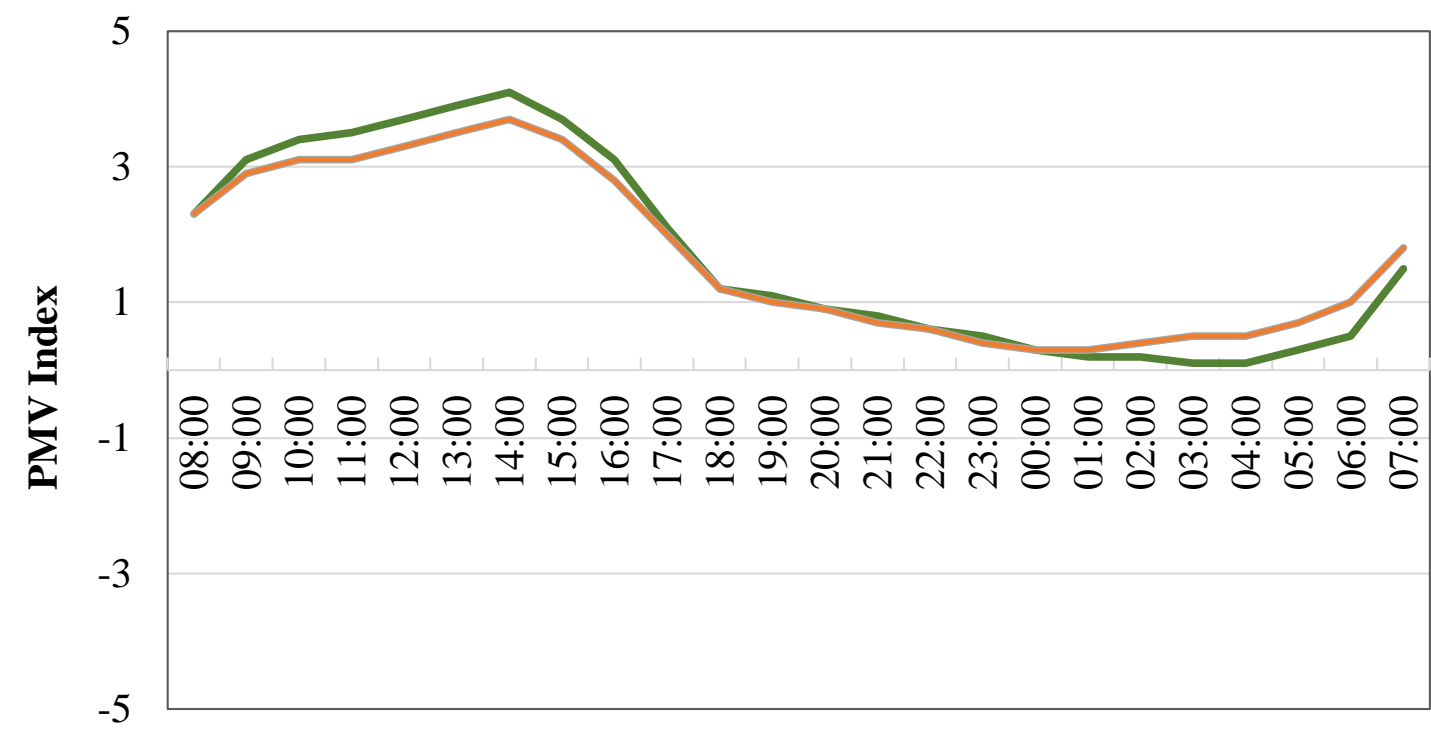

Time

-Mangrove $\longrightarrow$ Pavement $\longrightarrow$ Main Road

Figure 6. PMV at selected grids in 24 hours 
The result does not substantially mean that the Rayman has fully emulated the heat stress level in the study area. There is a limitation related to the fundamental of PMV and Rayman modelling. One of the variables in PMV calculation is human factors. In the real world, these factors include physiological, psychological, and socio-cultural factors (Yao et al., 2009). Since every model works as a simplification of the real world, aggregation is often found. In the PMV calculation, the aggregation especially defines the human factor. As a result, the human factor in PMV represents a one-dimensional human character that only corresponds to a single type of climate adaptation (mainly European climate). The PMV model does not take into account psychological and physiological adaptation (Kramer et al., 2017). Rayman also does not have an adjustment in its algorithm to compensate for the limitation.

The building of Rayman is heavily biased toward Caucasian white male. Therefore when Rayman is applied to a different cohort of race and gender, the result might come off as less representative. In the tropical climate, the local people are expected to have higher tolerance compared to European people. And females, reportedly have more tolerance than males, up to $2.5{ }^{\circ} \mathrm{C}$ higher (Kingma and van Marken Lichtenbelt, 2015).

Performing calibration is necessary to establish a more representative PMV index value. In practice, this would take a human monitoring study in a local scope. The monitoring would involve quantification of inhabitant perception toward thermal discomfort, which later used to develop a localized PMV index. By doing that, the temperature attribution for the PMV index would be expectedly more appropriate for local scope.

\section{CONCLUSIONS}

In summary, ENVI-MET simulation indicates that the existence of the mangrove area does affect air temperature distribution. The result shows that the mangrove cover has a cooling effect effectively after midnight (00.00 AM) to $11.00 \mathrm{AM}$ the next day. It also extends to the surrounding area, which belongs to artificial structures. In this area, the cooling effect emerges within an 8-hour window after 00.00 AM. However, it does not translate to thermal comfort improvement. The PMV results may not adequately reflect the reality in the field. Therefore, further research that involves human monitoring is required to calibrate PMV measurement to be more appropriate for tropical places like Tarakan.

\section{REFERENCES}

Adinna, E.N., Christian, E.I., and Okolie, A.T. 2009. Assessment of Urban Heat Island and Possible Adaptations in Enugu Urban using land SAT/ETM. Pakistan Journal of Social Sciences, 6: 26-31

Ambrosini, D., Galli, G., Mancini, B., Nardi, I., Sfarra, S. 2014. Evaluating Mitigation Effects of Urban Heat Islands in a Historical Small Center with the ENVI-Met ${ }^{\circledR}$ Climate Model. Sustainability 6, no. 10: 7013-7029.

American Society of Heating, Refrigerating and Air-Conditioning Engineers. 2017. ANSI/ASHRAE Standard 55-2017: Thermal Environmental Conditions for Human Occupancy. New York: The Society

Bornstein, R. D., \& Johnson, D. S. 1977. Urban-rural wind velocity differences. Atmospheric Environment (1967), 11(7), 597-604. doi:10.1016/00046981(77)90112-3

BPS Kota Tarakan. 2019. Statistik Sosial Ekonomi Kota Tarakan 2018. Badan Pusat Statistik Kota Tarakan.

BPS Provinsi Kalimantan Utara. 2019. Kalimantan Utara Province in Figure 2019. BPS-Statistics of Kalimantan Utara Province. 
Dobos, E. 2005. Albedo. University of Miskolc, Miskolc-Egyetemva'ros, Hungary.

Droste, A.M., Steeneveld, G.J., and Holtslag, A.A.M. 2018. Introducing the urban wind island effect. Environmental Research Letters 13 (2018), no. 9, 094007.

Karyono, T.H. 1995. Higher PMV Causes Higher Energy Consumption in AirConditioned Buildings: A Case Study in Jakarta, Indonesia. In: Standards for Thermal Comfort: Indoor Air Temperature Standards for the 21st Century, Chapman \& Hall, New York, 1995, pp. 219-226.

Kingma, B \& van Marken Lichtenbelt, W. 2015. Energy consumption in buildings and female thermal demand. Nature Climate Change. 5. 10.1038/nclimate2741.

Kramer, R., Schellen, L., Schellen, H., \& Kingma, B. 2017. Improving rational thermal comfort prediction by using subpopulation characteristics: A case study at Hermitage Amsterdam. Temperature (Austin, Tex.), 4(2), 187-197. doi:10.1080/23328940.2017.1301851

Manteghi, G., Lamit, H., Ossen, D., and Aflaki, A. 2016. Envi- Met Simulation on Cooling Effect of Melaka River. International Journal of Energy and Environmental Research. 4. 7-15.

Matzarakis, A., Rutz, F. and Mayer, H. 2007. Modelling Radiation Fluxes in Simple and Complex Environment - Application of the Rayman Model. Int. J. Biometeorol 51: 323. https://doi.org/10.1007/s00484-006-0061-8

Nuruzzaman, Md. 2015. Urban Heat Island: Causes, Effects and Mitigation Measures -A Review. International Journal of Environmental Monitoring and Analysis. 3. 67-73.

Salim, G., Rachmawani, D., and Agustianisa, R. 2019. Hubungan Kerapatan Mangrove Dengan Kelimpahan Gastropoda Di Kawasan Konservasi Mangrove Dan Bekantan (KKMB) Kota Tarakan. Jurnal Harpodon Borneo. Vol 12 No 1.
Sawitri, R., Bismark, M. and Karlina, E. 2013. Ekosistem Mangrove sebagai Obyek Wisata Alam di Kawasan Konservasi Mangrove Dan Bekantan Di Kota Tarakan. Jurnal Penelitian Hutan dan Konservasi Alam. Vol 10, No 3 (2013) 297-314.

Skoufali, I \& Battisti, A. 2019. Microclimate of Urban Canopy Layer and Outdoor Thermal Comfort: A Case Study in Pavlou Mela, Thessaloniki. Urban Science, 2019, 3, 84. doi:10.3390/urbansci3030084.

Taweekun, J., and Tantiwichien, A. 2013. Thermal Comfort Zone for Thai People. Engineering, Vol. 5 No. 5, 2013, pp. 525-529. doi: 10.4236/eng.2013.55062.

U.S. Environmental Protection Agency. 2008. Reducing urban heat islands: Compendium of strategies. Accessed 15/12/2019 https://www.epa.gov/heat-islands/heatisland-compendium.

Yao, R., Li, B., and Liu, J. 2009. A theoretical adaptive model of thermal comfort Adaptive Predicted Mean Vote (aPMV). Building and Environment. 44. 2089-2096. 